\title{
A Study on Correlation between Pore Water Pressure, Rainfall and Landslide Occurrence
}

\author{
Suhaimi, D.N.A.A ${ }^{1}$ and Selaman, O.S. ${ }^{2}$
}

\begin{abstract}
Landslides not only include loss of human lives and properties, but also effect the transportation direct and indirectly. This study focus on the correlation between rainfalls and pore water pressure which lead to landslide event. For this study, the scope of study focuses at Bau, Sarawak whereby lot of landslide event occurs along the road in 2009. Triaxial test is conduct in lab to measure pore water pressure which modeling landslide occurs on $11^{\text {th }}$ January 2009 at KM 72.00 Bau-Lundu Road. From the laboratory test, it can be seen that continuous and heavy rainfall will increase the pore water pressure in soil. When the pore water pressure increase from $809.94 \mathrm{kPa}$ to $829.25 \mathrm{kPa}$, the strength of the soil will be decrease due to the water content inside the soil. Other than that, correlation between pore water pressure and rainfall can be seen as an exponential relationship by plotting a graph using Microsoft Excel. It indicates that continuous rainfall within 11 days will increase the changes in pore water pressure and causes the soil to be in fully saturation condition. After 27 hours, the soil will be in failure which leads to landslide.
\end{abstract}

Keywords: Pore Water Pressure, Rainfall, Landslide

\section{INTRODUCTION}

$\mathrm{R}$ ain is the process where the condensed moisture of the atmosphere falling visibly in separate drops [1]. When the rains reach the ground surface, the water will soak into the earth and become groundwater and flows through a complicated routes which is finally discharged into river. Within the process, the pressure of the water that fills the void spaces between soil particles and rock fissures arises when the amount of water infiltrating into the ground increases. This situation is a major cause of landslides because it causes a drop in effective stress and affecting the stability of a slope.

Landslide usually happens at the mountains and hillsides. There are many cases reported towards this problem. The worst case landslides happen nowadays after landslide in 1993 (12-story condominium block collapsed) is at the Orphanage in Hulu Langat, Selangor where it cause 25 people died. This tragedy cause when the area had been saturated with rain for 2 days prior to the disaster and cause area loosening mud and rock.

There are many causes that can trigger landslide which are geological causes, morphological causes, physical causes and human causes. In Malaysia, the major landslide causes are the weathering (geological causes), soil properties (physical causes) and human activities (human causes) [2].

Much research had been conducted to find the causes of landslide occurrence. For example, the effect of rainfall infiltration on the stability of two residual soil slopes in Malaysia. This research shows that the infiltration of rainfall increases the self-weight and the mobilized shear stress of the slopes. It is because the infiltration of the rainfall into the slopes has reduced the matric suction in the slopes and the shear strength of the slopes [3].

\section{OVERVIEW OF THE STUDY AREA}

Sarawak has an equatorial climate which is hot and humid throughout the year. The temperature is relatively uniform within the range of $23^{\circ} \mathrm{C}$ to $32^{\circ} \mathrm{C}$ throughout the year. During the months of March to September, the weather is generally dry and warm. The average rainfall per year is between $3,300 \mathrm{~mm}$ and $4,600 \mathrm{~mm}$, depending on locality, and the wettest months are from November to February. Increasing rainfall and sea levels, and flooding has a significant effect to Sarawak [4].

Bau, Sarawak is chosen as the study area since no previous study on the relation of rainfall, pore water pressure and landslide has been made even though a lot of landslide cases happen. Bau is a unique place for this study. There have been cases about landslide occur at this place. For example, landslide in this area is at the Kampung Podium in 2004 where it causes death of 17 years old boy [5]. Other case is the resident of a housing estate in Bau, are living in fear of a landslide

${ }^{1}$ Lecturer, Academic Department, Center of Language and General Study, Technology College Sarawak, Sarawak, Malaysia, atika@tcs.edu.my

${ }^{2}$ Lecturer, Department of Civil Engineering, Faculty of Engineering, Universiti Malaysia Sarawak, Sarawak, Malaysia, sosuhaiza@feng.unimas.my 


\section{UNIMAS e-Journal of Civil Engineering: Volume 4, Issue 2}

from a hill that is not being properly retained and three landslides along the Bau-Lundu, Bau-Kuching and Bau-Matang roads in 2008 caused by heavy rain [6].

\section{Methodology}

i. Choosing Landslide Area

Year 2009 is chosen since there is no major landslide occurs during 2010 and 2011. Most of landslide occurs at Bau area caused by erosion, culvert problem, and embankment failure Jabatan Kerja Raya (Maintenance Department). Landslide cause of embankment failure occurs on $11^{\text {th }}$ January 2009 at KM 72.00 Luanda Bau Road is chosen for this study area since it gives a major impact to the environment and human.

ii. Rainfall

The rainfall station chosen are based on the nearest rainfall situation in the landslide area and this study focus on station 1401005, Bau station in Sungai Sarawak Basin.

iii. Pore Water Pressure

Test for pore water pressure is conducted in laboratory using a triaxial test. Undisturbed samples were collected by employing a cylindrical tube on thin wall sampling tubes of $100 \mathrm{~mm}$ diameter and $130 \mathrm{~mm}$ height for very soft to soft cohesive soils. After collection, the sampling tubes were sealed with transparent plastic to prevent any loss of moisture content.

\section{OVERVIEW OF THE RESULTS AND DISCUSSION}

i. Before the Rainfall

Before the test is conducted, the soil is assumed to be in dry condition (above the water table). The value of pore water pressure may be neglected and assumed to be zero.

ii. During the Rainfall (Saturation Phase)

During this saturation phase, pressure will be applied to force the water infiltrate into the soil (illustrate the rising in water table). To construct this situation, pressure inside the cell and back pressure from outside the cell must be approximately same.

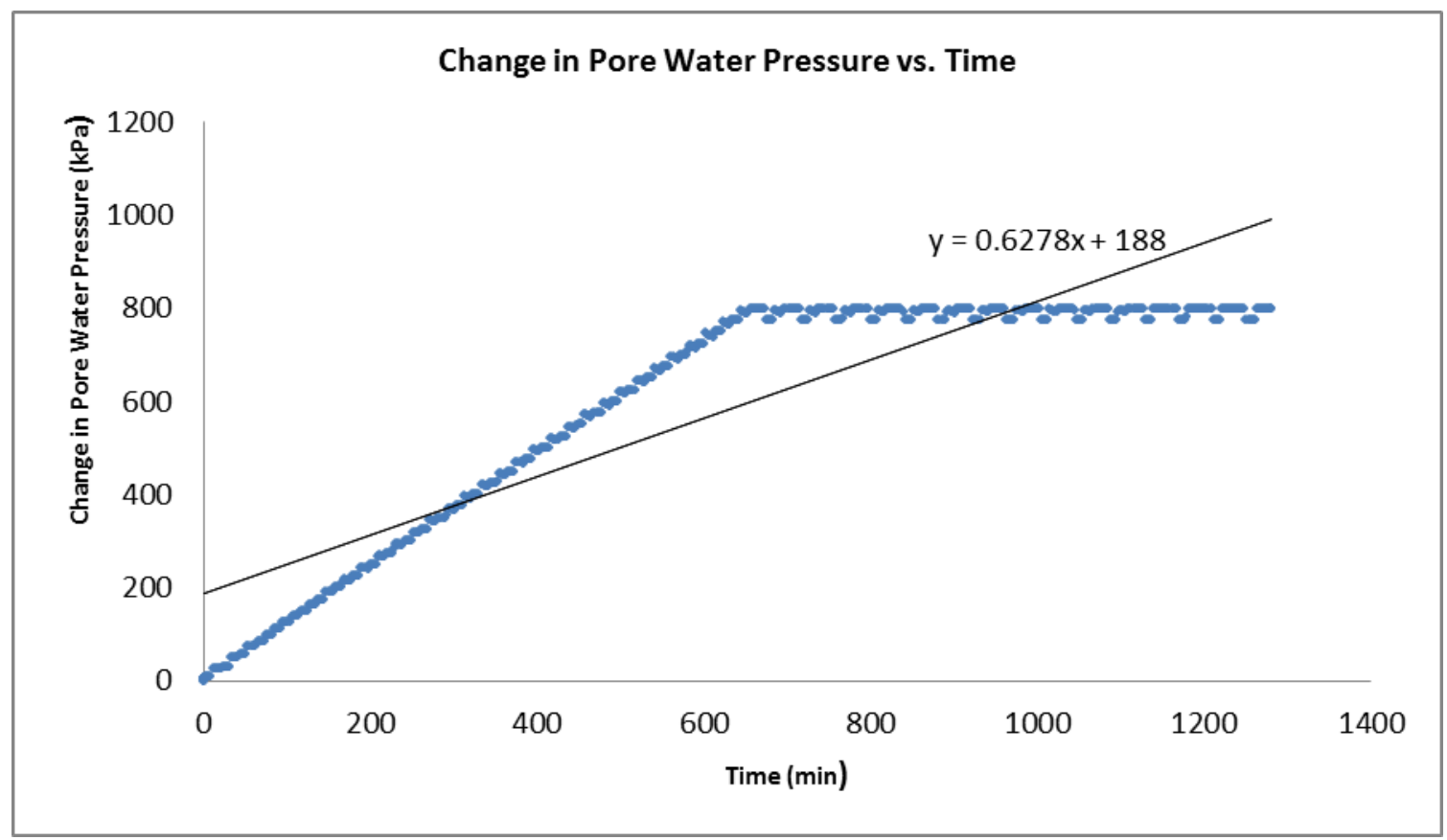

Figure 1: Change in Pore Water Pressure graph vs. Time

From the laboratory test, rate of increasing pore water pressure due to time obtain is $0.6278 \mathrm{kPa} / \mathrm{min}$ (Figure 1 ). Since other factors such as seepage force from infiltration is not considered into the calculation, both value obtain from laboratory test and from calculation $(0.7456 \mathrm{kPa} / \mathrm{min})$ is assumed to be same. There is not much different for both 
values which are only $0.1178 \mathrm{kPa}$. Pore water pressure at saturation phase is $809.94 \mathrm{kPa}$ with saturation ratio 0.96916 . This phase is conduct for 1314.1 minutes $(\approx 22$ hours) before the sample is fully saturated.

iii.At Failure

Sample failure occurs at minute $1619.5(\approx 27$ hours $)$ with the total vertical stress $995.76 \mathrm{kPa}$ and total horizontal stress $879.99 \mathrm{kPa}$. Value for pore pressure at this moment is $829.25 \mathrm{kPa}$ which can be considered high compare to pore water pressure obtain at the end of saturation phase (Figure 2).

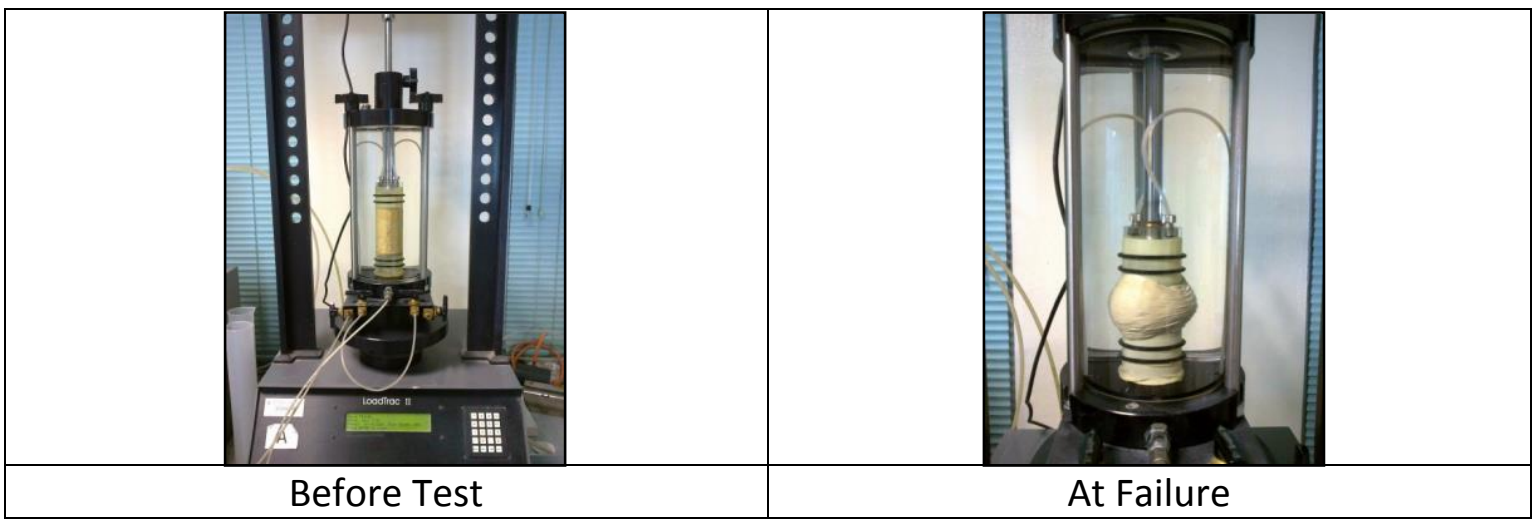

Figure 2: Soil condition Before Test and At Failure

iv. Rainfall Data and Pore Water Pressure

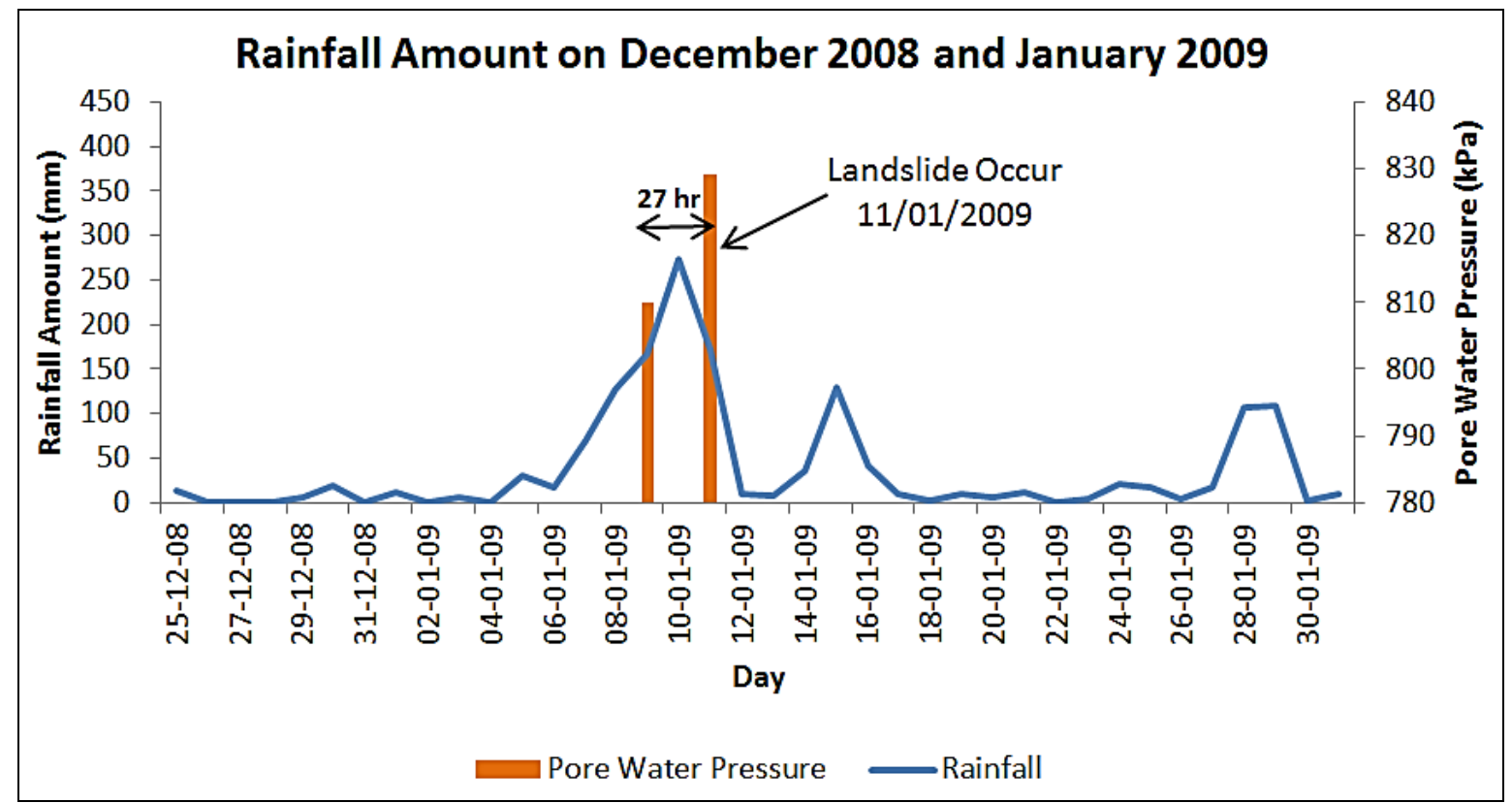

Figure 3: Day hyetograph and pore water pressure of Bau Station on December 2008 and January 2009

Before the landslide occur which is at the $9^{\text {th }}$ January 2009, pore water pressure inside the soil is increasing and assumed to be fully saturated since there is continuous rainfall occur. From the laboratory test that had been conduct, 27 hours (1 days, 3 hours) after the saturation phase end the soil will be at the failure phase which is believe the time when landslide occur at the prone area.

Value pore water pressure at the end of saturation which is $809.94 \mathrm{kPa}$ illustrating the actual condition at site before the landslide occurs. While value pore water pressure at failure which is $829.25 \mathrm{kPa}$ is illustrating the actual condition on site during the landslide occur. It can be clearly seen that pore water pressure changes rapidly at the end of saturation phase. 


\section{V.CONCLUSION}

By analyzing the amount of rainfall that triggers landslide occur at KM 72.00 Jalan Bau-Lundu, a prediction of future landslide occurrences could be done by relating the amount of rainfall as well as changes in pore water pressure in the 27 hours after the soil is fully saturation (continuously rainfall in 11 days) [6].

From this study of changes in pore water pressure by rainfall showed that the total rainfall and the changes in pore water pressure had an exponential relationship (Figure 3). The increasing of rainfall amount is consistent with the increasing of changes in pore water pressure. It indicates that constant rainfall within 11 days will increase the changes in pore water pressure and cause the soil in fully saturation condition. After 27 hours, the soil will be in failure phase which lead to landslide occurrence.

\section{ACKNOWLEDGEMENT}

The authors wish to express their gratitude to Department of Irrigation and Drainage (DID), Kota Samarahan, Kumpulan IKRAM Sdn. Bhd and Jabatan Kerja Raya (Maintenance Department) for providing the data.

\section{REFERENCES}

[1] Oxford. (2011). Rain. Retrieved October 2011, 28, from Oxford University Press: http://oxforddictionaries.com/definition/rain

[2] Horton, J. (1998). HowStuffWorks. Retrieved November 22, 2011, from How Landslides Work: http://science.howstuffworks.com/environmental/earth/geology/landslide3.htm

[3] Gui, M., \& Han, K. (2008). Landslides and Engineered Slopes. A case study on rainfall infiltration effect on the stability of two slopes, 1737-1743.

[4] Board, S. T. (2011). Climate/Weather. Retrieved October 28, 2011, from Fact On Sarawak: http://www.sarawaktourism.com

[5] Times, N. S. (2004, January 25). Retrieved October 30, 2011, from HighBeam Research: http://www.highbeam.com/doc/1P1-89808564.html

[6] Times, N. S. (2008, January). Heavy rain triggers landslides, floods in Bau. New Straits Times.

[7] Tay, J.E. \& Selaman O.S (2009). A Study on the Rainfall and Landslide Along Sarawak Road Using Antecedent Rainfall Analysis 